\title{
Comparison of two glucoamylases from Hormoconis resinae
}

\author{
Richard Fagerström,,${ }^{1 *}$ ArJa Vainio,${ }^{1}$ Kari Suoranta,,${ }^{1}$ Tinna Pakula, ${ }^{1}$ Nisse Kalkkinen ${ }^{2}$ \\ and HELENA TORKKELI ${ }^{1}$ \\ ${ }^{1}$ Research Laboratories, Alko Ltd, POB 350, SF-00101, Helsinki, Finland \\ ${ }^{2}$ Institute of Biotechnology, Helsinki University, Valimotie 7, SF-00380, Helsinki, Finland
}

(Received 19 October 1989; revised 2 January 1990; accepted 30 January 1990)

\begin{abstract}
Two extracellular glucoamylases (EC 3.2.1.3), glucoamylase $P$ and glucoamylase $S$, were purified to homogeneity from the culture medium of Hormoconis resinae (ATCC 20495; formerly Cladosporium resinae) by a new method. Their apparent molecular masses (71 kDa glucoamylase P; 78 kDa glucoamylase S) and catalytic properties agreed well with those previously reported in the literature. Heat inactivation studies suggested that the high debranching (1,6-glycosidic) activity of glucoamylase $P$ preparations (measured with pullulan) may reside in the same protein molecule as its 1,4-glycosidic activity (measured with soluble starch). Although glucoamylase $S$ had virtually no debranching activity, it cross-reacted with polyclonal antibodies raised against glucoamylase $\mathbf{P}$, and the two enzymes had very similar amino acid compositions. However, peptide mapping and amino-terminal sequencing studies of the peptides showed that the two enzymes have different sequences and must be encoded by different genes.
\end{abstract}

\section{Introduction}

Enzymes that degrade poly- and oligosaccharides are commercially important for the food and fermentation industries. Glucoamylases (1,4-glucan glucohydrolases; EC 3.2.1.3) release glucose units sequentially from the nonreducing end of polymeric carbohydrates. The ability of glucoamylases to hydrolyse 1,6-glycosidic bonds is called debranching activity and is of great importance in industrial processes requiring complete degradation of starch to glucose.

Glucoamylases are produced by a wide variety of micro-organisms (Manjunath et al., 1983). Most of the known glucoamylases have very low activity towards 1,6glycosidic bonds. The analytical measurement of debranching activity is not straightforward, since the activity of glucoamylases on substrates containing only 1,6-glycosidic bonds is usually quite low. To avoid this difficulty, substrates like pullulan (every third bond 1,6glycosidic) are often used to estimate 1,6-hydrolysing activity. Many fungal glucoamylases have been reported to exist in multiple forms (Lineback \& Bauman, 1970; Tsuboi et al., 1974; Yamasaki et al., 1977; Takahashi et al., 1978, 1981). In order to clone the appropriate gene it is essential to know if these multiple forms are coded by different genes, or if they are results of post-translational

Abbreviations: FMOC, 9-fluorenylmethoxycarbonyl; OPA, ophthalaldehyde; PTH, phenylthiohydantoin. modification and/or different mRNA splicing (Hayashida et al., 1988; Ono et al., 1988). For example, the two glucoamylases G1 and G2 produced by Aspergillus niger have identical amino-terminal sequences and peptide profiles but different carboxy-terminal sequences. According to Boel et al. (1984) these two forms of the enzyme are products of two differently spliced mRNA molecules coded by the same gene, whereas Svensson et al. (1986) have pointed out that proteolytic modification also affects the multiplicity of this enzyme.

The fungus Hormoconis resinae (ATCC 20495; formerly Cladosporium resinae) has been reported to produce two forms of glucoamylase which exhibit different substrate specificities and have different molecular masses and $\mathrm{pI}$ values (McCleary \& Anderson, 1980). The smaller glucoamylase $P$ has a very high debranching activity, while the larger glucoamylase $\mathrm{S}$ has virtually no debranching activity. In the present work, we examined whether the 1,4- and 1,6-glycosidic activities of glucoamylase $P$ are both functions of a single protein, and, secondly, whether glucoamylase $P$ and $S$ are products of a single gene or of two distinct genes.

\section{Methods}

Culture conditions. H. resinae (ATCC 20495) was stored as a suspension of spores in $0.1 \% \mathrm{SDS}$ and $10 \%(\mathrm{v} / \mathrm{v})$ glycerol at $-80^{\circ} \mathrm{C}$. A $1 \mathrm{ml}$ sample of this suspension was incubated at $30^{\circ} \mathrm{C}$ for $2 \mathrm{~d}$ in $50 \mathrm{ml}$ of 
a medium containing $2 \%(w / v)$ proteose peptone, $1 \%(w / v)$ yeast extract and $2 \%(\mathrm{w} / \mathrm{v})$ glucose. The cells were collected by centrifugation at $1000 \mathrm{~g}$ for $15 \mathrm{~min}$, washed once with $5 \mathrm{ml}$ sterile water and suspended in sterile water. The suspension was inoculated into a medium containing $1 \%(\mathrm{w} / \mathrm{v})$ proteose peptone and $0.2 \% \mathrm{NH}_{4} \mathrm{Cl}$ as nitrogen sources, $0.1 \%$ glucose and $2 \%(w / v)$ starch as carbon sounces and $0.2 \mathrm{M}$-potassium phosphate, $\mathrm{pH} 5.5$. One litre of medium was supplemented with $100 \mu \mathrm{g} \mathrm{CaCl}, 20 \mu \mathrm{g} \mathrm{FeSO}_{4} \cdot 7 \mathrm{H}_{2} \mathrm{O}, 50 \mu \mathrm{g}$ $\mathrm{MgSO}_{4} \cdot 7 \mathrm{H}_{2} \mathrm{O}, 100 \mu \mathrm{gnCl}_{2}, 10 \mu \mathrm{gnSO}_{4}, 100 \mu \mathrm{g} \mathrm{CuSO}_{4}, 10 \mu \mathrm{g}$ $\mathrm{CoCl}_{2}, 100 \mu \mathrm{g} \mathrm{NaMoO} .2 \mathrm{H}_{2} \mathrm{O}, 12.5 \mathrm{mg}$ tetracycline and $8.0 \mathrm{mg}$ chloramphenicol. The inoculated medium was incubated at $30^{\circ} \mathrm{C}$ in Erlenmeyer flasks filled to $10-15 \%$ of capacity and aerated by shaking ( 270 r.p.m.) at $30^{\circ} \mathrm{C}$. Samples of $2 \mathrm{ml}$ were taken from the cultures every $4-7 \mathrm{~d}$ to assay their ability to degrade starch and pullulan. Every $7 \mathrm{~d}, \operatorname{starch}\left(8 \mathrm{~g}^{-1}\right)$ was added to the culture. Growth was prolonged to between 24 and $27 \mathrm{~d}$, depending on the level of glucoamylase activity.

Activity measurements. The activity measurements were done as initial velocity measurements. Samples of $50 \mu \mathrm{l}$ were incubated at $30^{\circ} \mathrm{C}$ with $0.5 \%(\mathrm{w} / \mathrm{v})$ substrate in $0.1 \mathrm{M}$-sodium acetate $\mathrm{pH} 4.3$ containing $200 \mu \mathrm{g}$ bovine serum albumin $\mathrm{ml}^{-1}$ (Sigma; essentially fatty acid and globulin free) in a final volume of $1.0 \mathrm{ml}$. Samples were withdrawn at suitable time intervals (usually 0-30 min), and the reaction was stopped by the addition of $10 \mathrm{vols} 2 \%(\mathrm{v} / \mathrm{v})$ perchloric acid. After centrifugation at $15000 \mathrm{~g}$ for $5 \mathrm{~min}$, the glucose content of the supernatant was measured using a glucose dehydrogenase kit (Merck). One unit is defined as $1 \mu \mathrm{mol}$ glucose released in $1 \mathrm{~min}$.

Purification of glucoamylase. All steps were performed at $5{ }^{\circ} \mathrm{C}$. Cells were sedimented by centrifugation at $10000 \mathrm{~g}$ for $30 \mathrm{~min}$, and the supernatant was diluted with an equal volume of $0.2 \mathrm{M}$-potassium phosphate, pH 7.5, containing $0.2 \mathrm{~mm}$-EDTA and $2 \mathrm{mM}-\mathrm{MgCl}_{2}$. To this solution was added $250 \mathrm{~g}\left(\mathrm{NH}_{4}\right)_{2} \mathrm{SO}_{4} \mathrm{I}^{-1}$. The supernatant obtained by centrifugation for $20 \mathrm{~min}$ at $10000 \mathrm{~g}$ was diluted with $0.02 \mathrm{M}$-potassium phosphate, $\mathrm{pH} 7.5$, containing $0.1 \mathrm{mM}$-EDTA and $1 \mathrm{mM}-\mathrm{MgCl}_{2}$ (buffer A) to give a final concentration of $200 \mathrm{~g}$ $\left(\mathrm{NH}_{4}\right)_{2} \mathrm{SO}_{4} \mathrm{j}^{-1}$, and then applied at $200 \mathrm{ml} \mathrm{h}^{-1}$ to an Octyl-Sepharose CL-4B (Pharmacia) column $(5 \times 26 \mathrm{~cm})$ equilibrated with buffer $\mathrm{A}$ containing $200 \mathrm{~g}\left(\mathrm{NH}_{4}\right)_{2} \mathrm{SO}_{4} \mathrm{I}^{-1}$. Elution was performed with a linear gradient $(1000 \mathrm{ml})$ from $200 \mathrm{~g}\left(\mathrm{NH}_{4}\right)_{2} \mathrm{SO}_{4} 1^{-1}$ in buffer $\mathrm{A}$ to buffer $\mathrm{A}$ alone at $160 \mathrm{ml} \mathrm{h}^{-1}$. Fractions of $11 \mathrm{ml}$ were collected. The fractions degrading starch or starch and pullulan were pooled separately and $\left(\mathrm{NH}_{4}\right)_{2} \mathrm{SO}_{4}$ added at $450 \mathrm{~g} \mathrm{l}^{-1}$. The precipitate containing the enzyme was collected by centrifugation for $20 \mathrm{~min}$ at $10000 \mathrm{~g}$.

The pullulan-degrading fraction was purified as follows. The $\left(\mathrm{NH}_{4}\right)_{2} \mathrm{SO}_{4}$ precipitate was dissolved in $10 \mathrm{ml} 20 \mathrm{~mm}$-potassium phosphate, pH 7.5 (buffer B), then loaded onto and eluted at $180 \mathrm{ml} \mathrm{h}^{-1}$ from a Biogel P-30 (Bio-Rad) column $(3 \times 24 \mathrm{~cm})$ equilibrated with buffer $B$. The fractions $(4.8 \mathrm{ml})$ containing activity were pooled and then applied to an Accell QMA (Waters Associates) FPLC anionexchange column $(1 \times 10 \mathrm{~cm})$ equilibrated with buffer $B$. Elution was performed with a linear gradient of 0 to $0.3 \mathrm{M}-\mathrm{NaCl}$ in $80 \mathrm{ml}$ buffer $\mathrm{B}$. Fractions capable of degrading both pullulan and starch were pooled, diluted with water to less than $30 \mathrm{~mm}-\mathrm{NaCl}$, and applied to a Mono-P column $(0.5 \times 20 \mathrm{~cm}$; Pharmacia). The column was equilibrated with $25 \mathrm{~mm}-\mathrm{Bistris} / \mathrm{HCl}, \mathrm{pH} 6 \cdot 3$, and eluted at $30 \mathrm{ml} \mathrm{h}^{-1}$ with a mixture of $5 \mathrm{ml} \mathrm{PB}-74,1 \mathrm{ml}$ Pharmolyte $\mathrm{pH} 2.5-5$ (Pharmacia) and $100 \mathrm{ml} 25 \mathrm{mM}$ Bistris $/ \mathrm{HCl}, \mathrm{pH} 6 \cdot 3$, adjusted to $\mathrm{pH} 3.0$ with $\mathrm{HCl}$. To elevate the $\mathrm{pH}$ of the eluant immediately fractions of $0.5 \mathrm{ml}$ were collected into $0.2 \mathrm{ml}$ $0.5 \mathrm{M}$-Tris $/ \mathrm{HCl}, \mathrm{pH} \mathrm{6.8,} \mathrm{except} \mathrm{for} \mathrm{analytical} \mathrm{runs} \mathrm{where} \mathrm{the} \mathrm{pH}$ was monitored. Fractions containing the pullulan/starch-degrading activity were pooled, concentrated fivefold with Centricon 30 microconcentrators (Amicon), and $500 \mu$ l portions chromatographed on a Superose-12 column $(1 \times 30 \mathrm{~cm}$; Pharmacia) equilibrated with $0.05 \mathrm{M}$-potassium phosphate, $\mathrm{pH} 6.5$, containing $0.15 \mathrm{M}-\mathrm{NaCl}$, and eluted at $25 \mathrm{ml} \mathrm{h}^{-1}$.

The Octyl-Sepharose fraction that degraded only starch was purified as follows. The $\left(\mathrm{NH}_{4}\right)_{2} \mathrm{SO}_{4}$ precipitate was dissolved in $11 \mathrm{ml}$ buffer $\mathrm{B}$ and chromatographed on a Biogel P-30 column as above. Fractions containing activity were pooled and chromatographed on an Accell QMA anion-exchange column as above. Fractions containing starchdegrading activity were pooled, diluted with water to $30 \mathrm{mM}-\mathrm{NaCl}$ and applied to an FPLC Mono-Q column $(0.5 \times 5 \mathrm{~cm}$; Pharmacia) equitibated with $20 \mathrm{~mm}$-ammonium acetate, pH 6.3. Elution was performed at $60 \mathrm{ml} \mathrm{h}^{-1}$ th $0.3 \mathrm{M}-\mathrm{NaCl}$ gradient in $30 \mathrm{ml} 20 \mathrm{~mm}$ ammonium acetate, $\mathrm{pH} \mathrm{6.3.} \mathrm{Fractions} \mathrm{of} 7 \mathrm{mt}$. were collected. Fractions containing starch-degrading activity were diluted to $30 \mathrm{~mm}$ $\mathrm{NaCl}$, chromatographed on Mono-P, concentrated, and run on Superose 12 as above.

Purified preparations were stored at $-20^{\circ} \mathrm{C}$.

Amino acid composition. Protein samples in $50 \mathrm{~mm}$-potassium phosphate, $\mathrm{pH} 6 \cdot 5$, containing $0 \cdot 15 \mathrm{M}-\mathrm{NaCl}$ were hydrolysed with either $6 \mathrm{M}-\mathrm{HCl}\left(110^{\circ} \mathrm{C}, 24 \mathrm{~h}\right.$ and $\left.72 \mathrm{~h}\right)$ or $3 \mathrm{M}$-mercaptoethanesulphonic acid $\left(110^{\circ} \mathrm{C}, 24 \mathrm{~h}\right)$ (Penke et al., 1974; Reeck, 1987).

Amino acids were separated either by.HPLC (Varian Vista 5000 LL and AminoTag column) and quantified as FMOC derivatives (Varian Fluorichrom detector) (Einarsson et al., 1983), or by using a Kontron Liquimat III amino acid analyser equipped with an Interaction AA511 column and Pierce Buffelute buffers and quantified as OPA derivatives.

Peptide mapping by HPLC. Protein samples $(50-100 \mu \mathrm{g})$ containing. glucoamylase $\mathbf{P}$ or $\mathbf{S}$ activity were digested with lysylendopeptidase $\mathbf{C}$ (Wako Chemicals) in $70 \mathrm{~mm}$-Tris/ $\mathrm{HCl}$, pH 9.0 , at $37^{\circ} \mathrm{C}$ with $4 \%$ (w/w) of the protease for $20 \mathrm{~h}$. Trypsin (TPCK-treated, Sigma) digestions were performed by incubating similar samples at $37^{\circ} \mathrm{C}$ for $2 \mathrm{~h}$ with $3 \%$ $(\mathrm{w} / \mathrm{w})$ trypsin in the presence of $1 \%(w / v)$ ammonium bicarbonate and then with a further $2 \%(w / w)$ trypsin for about $18 \mathrm{~h}$.

The peptides were separated on a Vydac 218 TP B5 reverse-phase column $(0.46 \times 25 \mathrm{~cm}$; The Sep $/ \mathrm{a} / \mathrm{ra} / \mathrm{tions}$ Group, Hesperia, California, USA) using a Waters HPLC apparatus. Elution was performed at

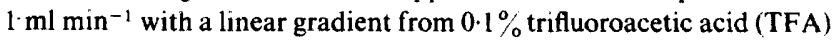
to $60 \%(\mathrm{v} / \mathrm{v})$ acetonitrile containing $0.05 \%$ TFA in $60 \mathrm{~min}$ at $30{ }^{\circ} \mathrm{C}$. Absorbance at $218 \mathrm{~nm}$ was measured.

Amino acid sequencing. Amino-terminal sequencing of the proteins and peptides was done by degrading them in a gas-pulsed-liquid-phase sequencer (Kalkkinen \& Tilgmann, 1988). The released PTH-amino acids were analysed on-line by using narrow-bore reverse-phase HPLC.

Production and purification of glucoamylase $P$ antibodies. Antibodies against purified glucoamylase $P$ were raised in rabbits. Samples of $50 \mu \mathrm{g}$ protein in $0.2 \mathrm{M}-\mathrm{NaCl}$ were emulsified with equal volumes of Freund's complete adjuvant and injected intradermally. Four additional doses of $50 \mu \mathrm{g}$ protein emulsified with Freud's incomplete adjuvant were given at 2 week intervals. The rabbits were bled by cardiac puncture 7-12 d after the last booster injection.

The antisera were purified by affinity chromatography on a column of Sepharose 4B (Pharmacia) that contained covalently linked purified glucoamylase $P$. The protein was coupled to Sepharose $4 B$ by cyanogen bromide according to Axén et al. (1967). Low-affinity antibodies were eluted with $0.1 \mathrm{M}$-sodium acetate, $\mathrm{pH} 4.5$. High-affinity antibodies were eluted with $0.1 \mathrm{M}$-glycine, $\mathrm{pH} 3 \cdot 0$. Fractions $(1 \mathrm{ml}$ ) were collected in tubes containing $35 \mu 1 \mathrm{l}$-Tris base. The purified antibody solution was adjusted to $\mathrm{pH} 7.5$ and stored at $-20{ }^{\circ} \mathrm{C}$.

Endoglycosidase treatment. SDS-treated samples (diluted to contain less than $0.2 \%, w / v$, SDS) were deglycosylated with Endo $\mathrm{H}$ of Streptomyces plicatus produced in S. lividans (Boehringer) in $0.1 \mathrm{M}$ sodium acetate, $\mathrm{pH} 5 \cdot 7$, containing $1 \%(\mathrm{w} / \mathrm{v})$ phenylmethylsulphonyl fluoride and $10 \mu \mathrm{M}$-pepstatin A (Sigma). The samples were incubated at $37^{\circ} \mathrm{C}$ for $20 \mathrm{~h}$ with $30 \mathrm{mU}$ of Endo $\mathrm{H}$ per $\mathrm{mg}$ of protein. 


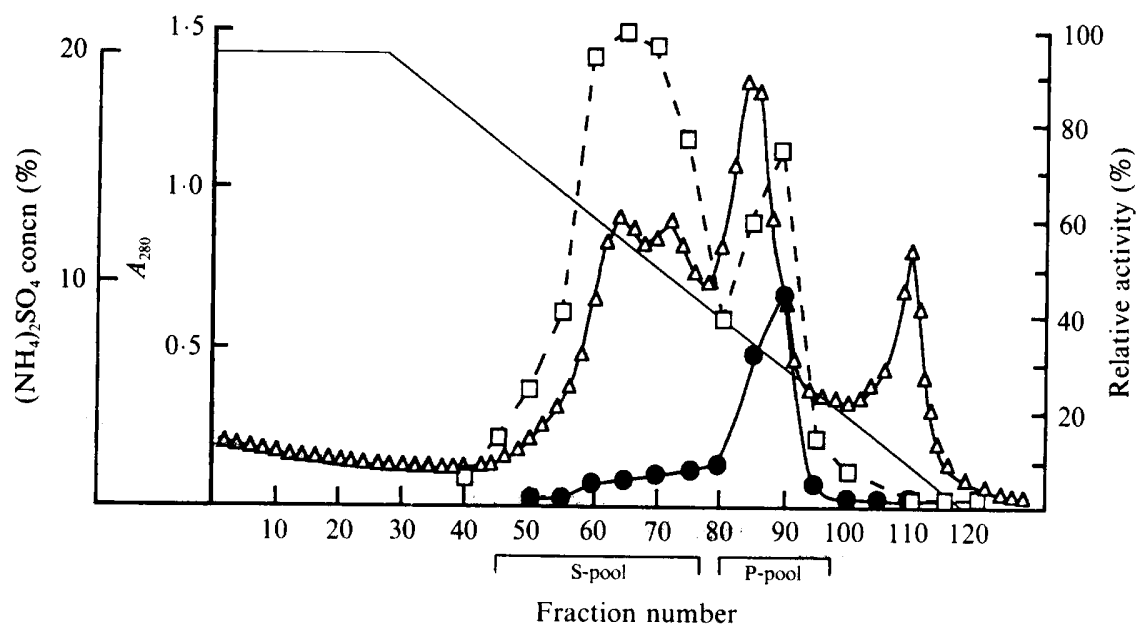

Fig. 1. Separation of glucoamylase $P$ and glucoamylase $S$ by Octyl-Sepharose $4 B$ chromatography. The column was run as described in Methods. $\triangle, A_{280} ; O$, relative activity measured with pullulan as substrate; $\square$, relative activity measured with starch as substrate; ,$-\left(\mathrm{NH}_{4}\right)_{2} \mathrm{SO}_{4}$ gradient. S-pool and $\mathrm{P}$-pool show fractions combined to purify glucoamylases $\mathrm{S}$ and $\mathrm{P}$, respectively. A relative activity of $100 \%$ corresponds to $1.32 \mathrm{U} \mathrm{ml}^{-1}$.

\section{Table 1. Purification of glucoamylase $P$ and glucoamylase $S$}

Activities were measured as described in Methods. The penultimate column shows the activity towards pullulan as a percentage of that towards starch. The recovery of glucoamylase $P$ was calculated from the activity towards pullulan. That of glucoamylase $\mathrm{S}$ is based on the activity towards starch and the calculation that, for the example shown, glucoamylase $\mathrm{P}$ is responsible for $28 \%$ of this activity in the growth medium (see text).

\begin{tabular}{|c|c|c|c|c|c|}
\hline Step & $\begin{array}{c}\text { Protein } \\
\left(\mathrm{mg} \mathrm{ml}^{-1}\right)\end{array}$ & $\begin{array}{c}\text { Pullulan } \\
\left(\mu \mathrm{mol} \mathrm{min}^{-1} \mathrm{mg}^{-1}\right)\end{array}$ & 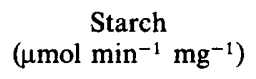 & $\begin{array}{c}\text { Debranching } \\
(\%)\end{array}$ & $\begin{array}{c}\text { Recovery } \\
(\%)\end{array}$ \\
\hline Growth medium & 0.45 & 0.7 & $3 \cdot 6$ & 20 & 100 \\
\hline $\begin{array}{l}\text { Glucoamylase P } \\
\text { Octyl-Sepharose } \\
\text { Accell QMA } \\
\text { Mono P } \\
\text { Superose } 12\end{array}$ & $\begin{array}{c}10.3 \\
0.94 \\
0.50 \\
0.38\end{array}$ & $\begin{array}{r}1 \cdot 2 \\
10 \cdot 4 \\
14 \cdot 1 \\
18 \cdot 3\end{array}$ & $\begin{array}{r}0 \cdot 9 \\
15 \cdot 0 \\
20 \cdot 3 \\
26 \cdot 1\end{array}$ & $\begin{array}{l}67 \\
70 \\
70 \\
70\end{array}$ & $\begin{array}{l}38 \\
30 \\
22 \\
22\end{array}$ \\
\hline $\begin{array}{l}\text { Glucoamylase } S \\
\text { Octyl-Sepharose } \\
\text { Accell QMA } \\
\text { Mono Q } \\
\text { Mono P } \\
\text { Superose } 12\end{array}$ & $\begin{array}{c}12.9 \\
3.4 \\
4.0 \\
0.9 \\
0.71\end{array}$ & $\begin{array}{l}0 \cdot 2 \\
0 \cdot 7 \\
0 \cdot 6 \\
0 \cdot 4 \\
0 \cdot 3\end{array}$ & $\begin{array}{r}2 \cdot 8 \\
6 \cdot 7 \\
9 \cdot 5 \\
19 \cdot 0 \\
24 \cdot 2\end{array}$ & $\begin{array}{r}14 \\
10 \\
6 \\
1 \\
1\end{array}$ & $\begin{array}{l}30 \\
19 \\
17 \\
15 \\
14\end{array}$ \\
\hline
\end{tabular}

Immunodiffusion. Glass plates covered with $0.8 \%(\mathrm{w} / \mathrm{v})$ low-meltingpoint agarose (Bethesda Research Laboratories) in $50 \mathrm{~mm}$-potassium phosphate, $\mathrm{pH} 7 \cdot 0$, containing $150 \mathrm{mM}-\mathrm{NaCl}$ were used. After $4 \mathrm{~d}$ of diffusion at room temperature, the plates were soaked in buffer for $10 \mathrm{~min}$ and dried under a stack of filter papers for $10 \mathrm{~min}$. This was repeated three times. Dry plates were stained with $1 \%(\mathrm{w} / \mathrm{v})$ amido black in $2 \%(\mathrm{v} / \mathrm{v})$ acetic acid for $30 \mathrm{~min}$. The stained plates were destained with $2 \%(\mathrm{v} / \mathrm{v})$ acetic acid.

Electrophoresis. Polyacrylamide slab gels (6-13\%) containing $0 \cdot 1 \%$ SDS were used and stained with Coomassie Brilliant Blue as described by Laemmli (1970).

Protein concentrations. The method of Bradford (1976) was used with $\gamma$-globulin as standard. Turbid protein samples, such as the growth medium, were first precipitated with perchloric acid. Proteins being eluted from the chromatographic columns were monitored at $280 \mathrm{~nm}$.
Chemicals. Pullulan was from Sigma and Zulkowsky starch from Merck. Partially purified Aspergillus niger and Rhizopus delemar glucoamylases were from Sigma.

\section{Results}

The purification procedures are summarized in Table 1. The Octyl-Sepharose column separated the starch(glucoamylase S) and pullulan/starch- (glucoamylase P) degrading activities (Fig. 1). The Accell QMA step gave a relatively large purification of both enzymes. A small polypeptide (about $32 \mathrm{kDa}$ ) still present in glucoamylase $P$ preparations after the Mono $P$ column was removed by 


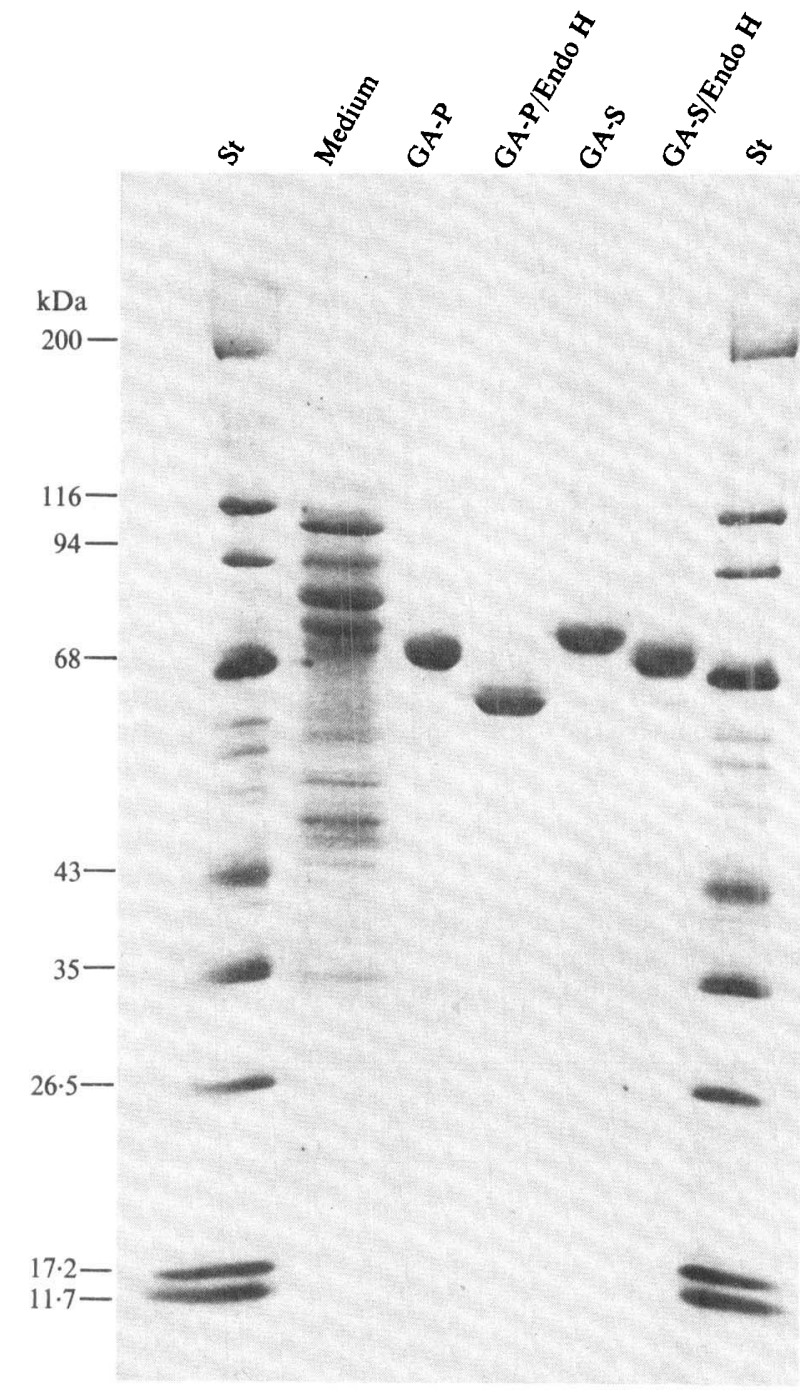

Fig. 2. SDS-PAGE analysis of the glucoamylases. Growth medium (Medium), purified glucoamylases $\mathrm{P}$ and $\mathrm{S}$ before (GA-P, GA-S) and after (GA-P/Endo $\mathrm{H}, \mathrm{GA}-\mathrm{S} /$ Endo $\mathrm{H}$ ) treatment with endoglycosidase $\mathrm{H}$ and molecular mass standards [St: myosin $(200 \mathrm{kDa}), \beta$-galactosidase $(116 \mathrm{kDa})$, phosphorylase $(94 \mathrm{kDa})$, bovine serum albumin $(68 \mathrm{kDa})$, ovalbumin $(43 \mathrm{kDa})$, lactate dehydrogenase $(35 \mathrm{kDa})$, triosephosphate isomerase $(26.5 \mathrm{kDa})$, myoglobin $(17.2 \mathrm{kDa})$ and cytochrome $c(11.7$ $\mathrm{kDa})$ ] were run on a $6-13 \%$ polyacrylamide slab gel and stained with Coomassie Brilliant Blue as described in the text.

gel exclusion chromatography on Superose 12 . The ratio of activities towards pullulan and starch changed by only a few percent during the 15 -fold purification of glucoamylase P from the Octyl-Sepharose P-pool, and was constant through the last two purification steps. Residual debranching activity in the S-pool from Octyl-Sepharose was mostly removed by the Accell QMA, Mono Q and Mono P columns. The final step (Superose 12) caused no further change in the proportion of debranching activity $(1 \%)$ but caused a $25 \%$ increase in specific activity and

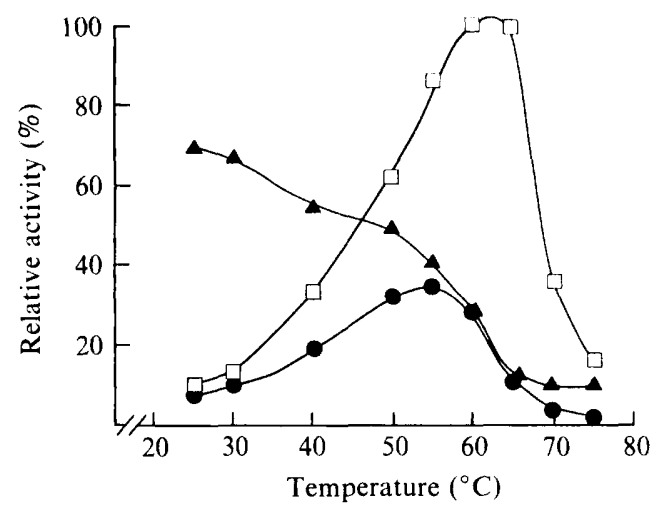

Fig. 3. Temperature dependence of glucoamylase $P$ activity. Samples of $50 \mu$ lenzyme protein solution were incubated at different temperatures

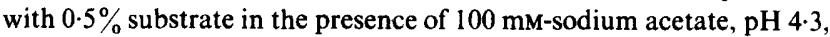
containing $0.2 \mathrm{mg}$ bovine serum albumin $\mathrm{ml}^{-1}$. At suitable times (the same for starch as for pullulan at each temperature) samples were withdrawn and assayed for released glucose as described in Methods. The activity of starch degradation at $60^{\circ} \mathrm{C}\left(11.2 \mathrm{U} \mathrm{ml}^{-1}\right)$ was taken as $100 \%$ relative activity. The activities with pullulan $(\odot)$ or starch $(\square)$ as substrate, and their ratio (pullulan $\times 100 /$ starch) $(\boldsymbol{\Lambda})$ are shown

removed the polybuffer components from the preparation. The purified preparations were both stable at $-20{ }^{\circ} \mathrm{C}$ for at least a year.

The recovery of glucoamylase $\mathrm{P}$ was $22 \%$ calculated from the total pullulan-degrading activity, and the purification was 27-fold (Table 1). The recovery of glucoamylase $\mathrm{S}$ could not be calculated from the total starch-degrading activity of the growth medium, because glucoamylase $P$ also degrades starch. The contribution of glucoamylase $\mathbf{P}$ was calculated on the basis that the activity of purified glucoamylase $P$ towards starch was 1.43 times its activity towards pullulan, whereas purified glucoamylase $\mathrm{S}$ had negligible activity towards pullulan. On this basis, recovery of glucoamylase $\mathrm{S}$ was $14 \%$ with a purification of ninefold (Table 1). Both enzymes appeared homogeneous on SDS-PAGE, and had apparent molecular masses of $71 \mathrm{kDa}$ (glucoamylase $\mathrm{P}$ ) and $78 \mathrm{kDa}$ (glucoamylase S) (Fig. 2). The deglycosylated proteins showed apparent molecular masses of $63 \mathrm{kDa}$ and $71 \mathrm{kDa}$ respectively, giving an apparent glycosylation of $11 \%$ for glucoamylase $P$ and $9 \%$ for glucoamylase S. Analytical runs on Superose 12 gave apparent molecular masses of $72 \mathrm{kDa}$ (glucoamylase P) and $81 \mathrm{kDa}$ (glucoamylase $\mathrm{S}$ ) for the native proteins (results not shown). The isoelectric points obtained from the chromatofocusing experiments (not shown) were 3.8 for glucoamylase $P$ and $4 \cdot 1$ for glucoamylase $S$.

The $\mathrm{pH}$ optimum for both enzymes was broad at $30^{\circ} \mathrm{C}$ with maximum activity between pH 3.5 and 4.6 (results not shown). The temperature dependence of the activities of glucoamylase $P$ is shown in Fig. 3. 


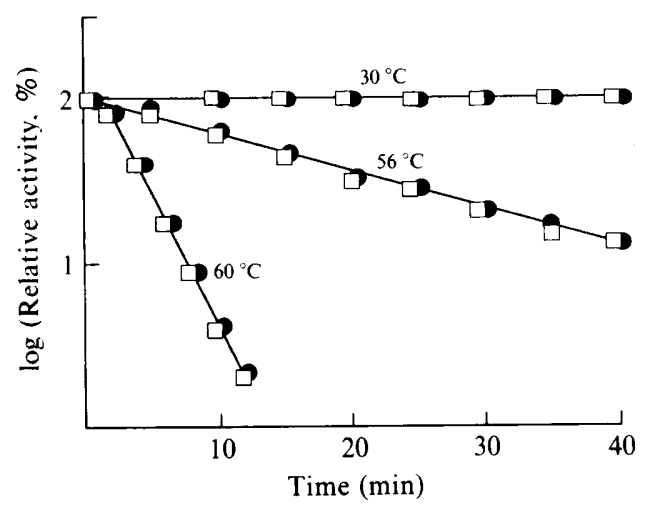

Fig. 4. Thermal inactivation of glucoamylase $P$. Three samples of 1080 $\mu \mathrm{l}$ of purified enzyme protein were incubated at $30^{\circ} \mathrm{C}, 56^{\circ} \mathrm{C}$ and $60^{\circ} \mathrm{C}$, respectively, in $50 \mathrm{~mm}$-potassium phosphate, $\mathrm{pH} 6.5$. At suitable times, samples of $50 \mu \mathrm{l}$ were withdrawn and assayed at $37^{\circ} \mathrm{C}$ with pullulan or starch as described in Methods. A relative activity of $100 \%$ corresponds to $0.9 \mathrm{U} \mathrm{ml}^{-1}$ for starch-degrading activity and $0.5 \mathrm{U} \mathrm{ml}^{-1}$ for pullulan-degrading activity. $\mathbf{O}$, Pullulan as substrate; $\square$, starch as substrate.

Fig. 4 shows the thermal inactivation of purified glucoamylase $\mathrm{P}$ at $30^{\circ} \mathrm{C}, 56{ }^{\circ} \mathrm{C}$ and $60^{\circ} \mathrm{C}(\mathrm{pH} \mathrm{6.5)}$ with both pullulan and starch as substrates. Identical thermal inactivation profiles were obtained for the two substrates.

The amino acid compositions of the two enzymes were very similar (Table 2). Antibodies raised in rabbits against glucoamylase $\mathbf{P}$ and purified by binding to immobilized glucoamylase $P$ gave a precipitation band with glucoamylase $\mathrm{P}$, but also with glucoamylase $\mathrm{S}$ when the latter was used in at least three times greater amounts than those of the glucoamylase $\mathrm{P}$ (results not shown). No precipitation bands were found when the $H$. resinae glucoamylases were substituted by commercial preparations of glucoamylases from Aspergillus niger and Rhizopus delemar even in excess.

Many attempts were made to digest glucoamylases $\mathbf{P}$ and $S$ with yeast carboxypeptidase $Y$, but no amino acids were released. Both nonalkylated samples (in $5 \mathrm{M}$-urea) and alkylated (Friedman et al., 1970; Fullmer, 1984) samples were treated with carboxypeptidase for various times and then derivatized with Dabs- $\mathrm{Cl}$ (Chang et al., 1983) before amino acid analysis. Under identical conditions, the correct carboxy-terminal sequence (-Leu/Gly-Phe-Gln-Gly-OH) was obtained for equine skeletal muscle myoglobin.

Different peptide maps were obtained from glucoamylase $\mathbf{P}$ and $\mathrm{S}$, respectively, after digestion with either lysylendopeptidase C (Fig. 5) or trypsin (results not shown).

The amino-terminal sequences of the native proteins were distinct, but showed $59 \%$ identity in the first 22 residues (Table 3). Several pairs of peptides (one member
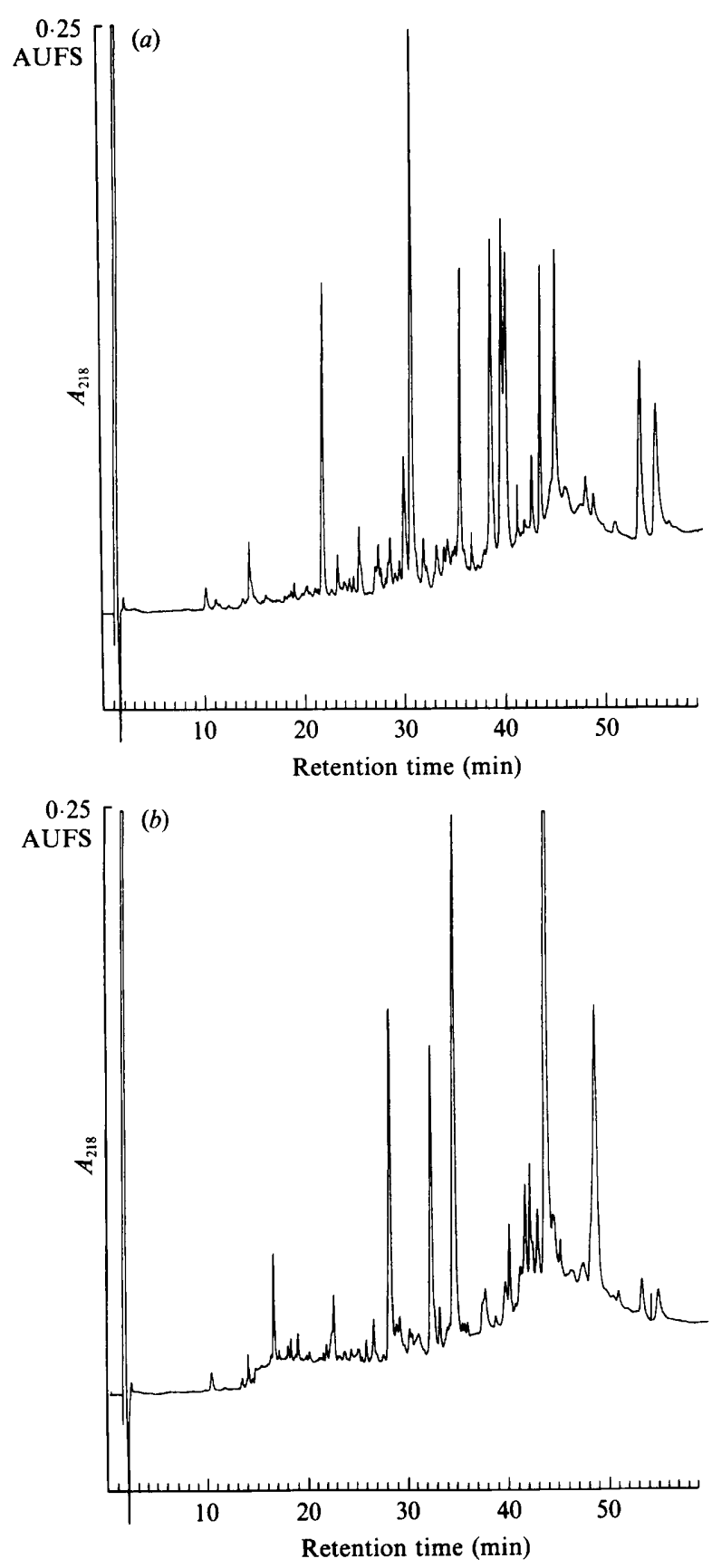

Fig. 5. Peptide profiles of ( $a$ ) glucoamylase $\mathbf{P}$ and $(b)$ glucoamylase $\mathrm{S}$ digested with lysylendopeptidase $C$. Protein samples were digested with lysylendopeptidase $C$ and the resulting peptides were separated by reverse-phase HPLC as described in Methods. Peptides were monitored at $218 \mathrm{~nm}$.

from each enzyme) were also found that had distinct but similar amino-terminal sequences: S lys-C $28 \cdot 1$ and $P$ trypsin 21.4 ( $78 \%$ identity over 27 amino acids); S lys-C 32.2 and $P$ trypsin 35.0 (50\% identity over 20 amino acids); $S$ trypsin 26.0 and $P$ lys-C 39.8 (63\% identity over 8 amino acids); $\mathrm{S}$ trypsin 23.9 and $\mathrm{P}$ trypsin $20.1(80 \%$ 
Table 2. Amino acid composition of glucoamylase $P$ and $S$

The amino acid contents of the glucoamylases were analysed as described in Methods. For residues marked with asterisks, results from mercaptoethanesulphonic acid hydrolysates were used; other results are from $6 \mathrm{M}-\mathrm{HCl}$ hydrolysates. For cysteine the average value from several glucoamylases (Manjunath et al., 1983) was used.

\begin{tabular}{|c|c|c|c|c|}
\hline \multirow[b]{2}{*}{$\begin{array}{l}\text { Amino } \\
\text { acid }\end{array}$} & \multicolumn{2}{|c|}{ Glucoamylase P } & \multicolumn{2}{|c|}{ Glucoamylase S } \\
\hline & $\begin{array}{c}\text { Content } \\
(\mathrm{mol} \text { per } 100 \mathrm{~mol})\end{array}$ & $\begin{array}{l}\text { No. of residues } \\
\text { (per } 63000 \mathrm{Da} \text { ) }\end{array}$ & $\begin{array}{c}\text { Content } \\
\text { (mol per } 100 \mathrm{~mol})\end{array}$ & $\begin{array}{l}\text { No. of residues } \\
\text { (per } 71000 \mathrm{Da} \text { ) }\end{array}$ \\
\hline Asx & 11.0 & $63 \cdot 3$ & $10 \cdot 8$ & $69 \cdot 7$ \\
\hline Thr* & $8 \cdot 5$ & 48.9 & $10 \cdot 0$ & $64 \cdot 6$ \\
\hline Ser* & $9 \cdot 5$ & 54.5 & $11 \cdot 7$ & $75 \cdot 4$ \\
\hline Glx & $8 \cdot 2$ & $46 \cdot 8$ & 8.8 & 56.8 \\
\hline Pro & 5.9 & 33.9 & 3.8 & 24.8 \\
\hline Gly & $7 \cdot 9$ & $45 \cdot 3$ & 6.8 & $43 \cdot 9$ \\
\hline Ala & 11.0 & $63 \cdot 3$ & $7 \cdot 8$ & $50 \cdot 6$ \\
\hline Cys.SH & 1.4 & 8 & 1.2 & 8 \\
\hline Val & $5 \cdot 6$ & 31.9 & $5 \cdot 2$ & $33 \cdot 6$ \\
\hline -Met" & 0.9 & $5 \cdot 1$ & 1.0 & $6 \cdot 7$ \\
\hline Ile & $5 \cdot 4$ & $30 \cdot 9$ & $4 \cdot 7$ & $30 \cdot 5$ \\
\hline Leu & 6.8 & $39 \cdot 1$ & $7 \cdot 4$ & 47.5 \\
\hline Tyr* & 5.8 & $33 \cdot 4$ & $6 \cdot 2$ & $40 \cdot 3$ \\
\hline Phe & 3.6 & $20 \cdot 6$ & $4 \cdot 4$ & 28.4 \\
\hline His & $1 \cdot 2$ & $6 \cdot 7$ & 1.4 & $9 \cdot 3$ \\
\hline Lys & $2 \cdot 0$ & $11 \cdot 3$ & $2 \cdot 6$ & 17.0 \\
\hline Trp* & $2 \cdot 1$ & 11.8 & $2 \cdot 3$ & 15.0 \\
\hline Arg & $3 \cdot 1$ & 18.0 & $3 \cdot 6$ & $23 \cdot 2$ \\
\hline
\end{tabular}

Table 3. Amino acid sequence of the $N$-terminus and $N$-terminal peptide sequences from glucoamylase $P$ and glucoamylase $S$

Amino-terminal sequences of native glucoamylases $P$ and $S$ as well as peptides isolated by HPLC from trypsin and lysylendopeptidase digests were performed with a gas-phase sequencer as described in Methods. Peptides are numbered according to their appearance time in the peptide maps. Lys-C, lysylendopeptidase C; GA-P, glucoamylase P; GA-S, glucoamylase S; $x$, not determined.

\begin{tabular}{|c|c|c|c|}
\hline Source & Digest & Peptide & Sequence \\
\hline $\begin{array}{l}\text { GA-S } \\
\text { GA-P }\end{array}$ & $\begin{array}{l}\text { None } \\
\text { None }\end{array}$ & $\begin{array}{l}\text { N-term. } \\
\text { N-term. }\end{array}$ & $\begin{array}{l}\text { SVDSF I ESEYA I ALADLLXNIG } \\
\text { DLSSE I ASERA I ALOGALNN IGPD }\end{array}$ \\
\hline $\begin{array}{l}\text { GA-S } \\
\text { GA-P }\end{array}$ & $\begin{array}{l}\text { Lys-C } \\
\text { Trypsin }\end{array}$ & $28 \cdot 1$ & $\begin{array}{l}\text { TAFTGSWGRPQRDGPALRATALI AYSK } \\
|||||||| \mid=110 \\
\text { ENGPWGRPQR }\end{array}$ \\
\hline $\begin{array}{l}\text { GA-S } \\
\text { GA-P }\end{array}$ & $\begin{array}{l}\text { Lys-C } \\
\text { Trypsin }\end{array}$ & $\begin{array}{l}32 \cdot 2 \\
35 \cdot 0\end{array}$ & TGLDGNSILGA I STEDIDAYCDS \\
\hline GA-S & Trypsin & $\begin{array}{l}26 \cdot 0 \\
39 \cdot 8\end{array}$ & $\begin{array}{l}\text { ILANINEN } \\
\text { YIVSNINVNNGRTG }\end{array}$ \\
\hline GA-S & Trypsin & 23.9 & QSXGSLSEOES \\
\hline GA-P & Trypsin & $20 \cdot 1$ & Y I PSXGSLSEQFNR \\
\hline GA-S & Trypsin & $42 \cdot 6$ & $\begin{array}{l}\text { VNPDYFY } \\
\mid\|\| \| !\end{array}$ \\
\hline GA-P & Lys-C & $30 \cdot 5$ & ANPDYEYTWSRDSALTLK \\
\hline $\begin{array}{l}\text { GA-S } \\
\text { GA-P }\end{array}$ & $\begin{array}{l}\text { Trypsin } \\
\text { Trypsin }\end{array}$ & $16 \cdot 7$ & $\begin{array}{l}\text { TLAAOHR } \\
|||| \mid \\
\text { TIQNOHR }\end{array}$ \\
\hline
\end{tabular}


identity over 10 amino acids); $S$ trypsin 42.6 and $P$ lys- $C$ 30.5 (86\% identity over 7 amino acids) and $S$ trypsin 16.7 and $P$ trypsin 11.0 (57\% identity over 7 amino acids) (Table 3).

\section{Discussion}

The separation of glucoamylase $\mathrm{P}$ and $\mathrm{S}$ by hydrophobic interaction chromatography is effective, and also convenient because it can easily be scaled up for commercial-scale purification. The optimal ratio of 1,6- to 1,4glucosidic activity (as well as other amylolytic activities) in starch degradation depends greatly on the process and substrate used (Labout, 1985; Kennedy et al., 1988). Hence, large-scale purification of glucoamylase $\mathbf{P}$ may be important, if the debranching activity is to be used efficiently in industrial processes.

The apparent molecular masses (glucoamylase $P$, $71 \mathrm{kDa}$; glucoamylase S, $78 \mathrm{kDa}$ ) estimated by SDSPAGE were only slightly different from the values reported by McCleary \& Anderson (1980) (70 kDa and $82 \mathrm{kDa}$, respectively), and the specific activities were also similar. The molecular masses of the native proteins estimated by gel exclusion chromatography indicate that both enzymes are monomeric in their native states.

The activity ratio of glucoamylase $P$ towards pullulan compared to starch decreased when the temperature was increased (Fig. 3). This behaviour could result from a stabilization of glucoamylase $\mathbf{P}$ by the higher concentration of non-reducing end-groups in starch compared to pullulan, as proposed by McCleary \& Anderson (1980).

The identical thermal inactivations of the two activities in glucoamylase $P$ (Fig. 4) makes the presence of two enzymes in the preparation very unlikely.

A covalently blocked carboxy-terminus could be responsible for the failure of carboxypeptidase $\mathrm{Y}$ to release amino acids from glucoamylase $P$ and glucoamylase S. Another possibility could be that the carboxyterminal sequence is inaccessible to carboxypeptidase $Y$ even in the presence of $5 \mathrm{M}$-urea.

The peptide maps of glucoamylases $\mathrm{P}$ and $\mathrm{S}$ showed large differences, but amino acid sequences of some of the corresponding peptides had high identity. Whereas the high percentage identity seems to indicate a homology between the two enzymes, the differences between the highly similar sequences, especially between the amino-terminal sequences of the proteins, shows that they must be coded by different mRNA species. A combination of intron splicing and post-translational modification is very unlikely, because so many splicing events would be required to generate the widely scattered sequence differences observed. This is also supported by the larger amount of proline and alanine in the smaller glucoamylase $\mathbf{P}$ compared to the larger glucoamylase $\mathbf{S}$. Thus, the two enzymes must be encoded by distinct genes.

The cross-reactivity of the glucoamylase $P$ polyclonal antibodies with glucoamylase $\mathbf{S}$ indicates some similar antigenic determinants in either the carbohydrate or protein portions of the two enzymes.

Putative homologies between various sequenced glucoamylases have recently been described (Tanaka et al., 1986; Itoh et al., 1987). There seem to be five distinct regions (S1 to S5) of high homology in glucoamylases. Sequences similar to parts of the $S 1$ consensus sequence (G---AS-S---PDY-Y-W-RD----) are found (Table 3) in the peptides GA-S trypsin 42.6 (PDYFY) and GA-P lysC 30.5 (PDYFYTWSRD). Sequences similar to parts of the $\mathrm{S} 2$ consensus sequence (LG-PK-N-D----T-WGRPQ-DGPA-R---) are found in the peptides GA-S lys-C 28.1 (TGSWGRPQRDGPALR) and GA-P tryp$\sin 21.4$ (WGRPQ).

Further sequencing is necessary in order to find the overall homology to other glucoamylases, as well as the homology of glucoamylases $\mathbf{P}$ and $\mathbf{S}$.

We thank Ms Jaana Pekurinen and Mr Asko Rieppola for technical assistance, and Dr John Londesborough for reading the manuscript.

\section{References}

Axén, R., Porath, J. \& Ernback, S. (1967). Chemical coupling of peptides and proteins to polysaccharides by means of cyanogen halides. Nature, London 214, 1302-1304.

Boel, E., Huort, I., Svensson, B., Norris, F., Norris, K. E. \& Fill, N. P. (1984). Glucoamylases G1 and G2 from Aspergillus niger are synthesized from two different but closely related mRNAs. EMBO Journal 3, 1097-1102.

BRADFORD, M. (1976). A rapid and sensitive method for the quantitation of microgram quantities of protein utilizing the principle of protein-dye binding. Analytical Biochemistry 72, 248254.

Chang, J. Y., KNECht, R. \& Braun, D. G. (1983). Amino acid analysis in the picomole range by precolumn derivatization and highperformance liquid chromatography. Methods in Enzymology 91, 4148.

EINARSSON, S., JosefsSon, B. \& LAGERKvist, S. (1983). Determination of amino acids with 9-fluorenylmethyl chloroformate and reversedphase high-performance liquid chromatography. Journal of Chromatography 282, 609-618.

Friedman, M., Krull, L. H. \& Cavins, J. F. (1970). Reactions of amino acids, peptides and proteins with $\alpha, \beta$-unsaturated compounds. XIV. Chromatographic determination of cystine and cysteine residues in proteins as $S$ - $\beta$-(4-pyridylethyl)cysteine. Journal of Biological Chemistry 245, 3868-3871.

FULLMER, C. S. (1984). Identification of cysteins-containing peptides in protein digests by high-performance liquid chromatography. Analytical Biochemistry 142, 336-339.

Hayashida, S., Nakahara, K., Kuroda, K., Kamachi, T., Ohta, K., Iwanaga, S., MiYata, T. \& Sakaki, Y. (1988). Evidence for posttranslational generation of multiple forms of Aspergillus awamori glucoamylase. Agricultural and Biological Chemistry 52, 273-275.

Itoh, T., OHTsuki, I., Yamashita, I. \& FuxuI, S. (1987). Nucleotide sequence of the glucoamyiase gene GLUI in the yeast Saccharomycopsis fibuligera. Journal of Bacteriology 169, 4171-4176. 
Kalkkinen, N. \& Tilgmann, C. (1988). A gas-pulsed-liquid-phase sequencer constructed from a Beckman $890 \mathrm{D}$ instrument by using Applied Biosystems delivery and cartridge blocks. Journal of Protein Chemistry 7, 242-243.

Kennedy, J. F., Cabalda, V. M. \& White, C. A. (1988). Enzymic starch utilization and genetic engineering. Trends in Biotechnology 6 , 184-189.

LABOUT, J. J. M. (1985). Conversion of liquefied starch into glucose using a novel glucoamylase system. Starch/Stärke 37, 157-161.

LAEMMLI, U. K. (1970). Cleavage of structural proteins during the assembly of the head of bacteriophage T4. Nature, London 227, 680685.

Lineback, D. R. \& Bauman, W. E. (1970). Properties of a glucoamylase from Aspergillus phoenicis. Carbohydrate Research 14, 341-353.

Manjunath, P., Shenoy, B. C. \& Raghavendra Rao, M. R. (1983). Fungal glucoamylases. Journal of Applied Biochemistry 5, 235-260.

MCCleary, B. V. \& ANDERson, M. A. (1980). Hydrolysis of $\alpha$-Dglucans and $\alpha$-D-gluco-oligosaccharides by Cladosporium resinae glucoamylases. Carbohydrate Research 86, 77-96.

Ono, K., Shintani, K., Shigeta, S. \& OKa, S. (1988). Various molecular species in glucoamylase from Aspergillus niger. Agricultural and Biological Chemistry 52, 1689-1698.

Penke, B., Ferenczi, R. \& Kovacs, K. (1974). A new acid hydrolysis method for determining tryptophan in peptides and proteins. Analytical Biochemistry 60, 45-50.
ReECK, G. (1987). Amino acid compositions of selected proteins. In CRC Handbook of Biochemistry and Molecular Biology, vol. 3., Proteins, 3rd edn, pp. 504-519. Edited by G. D. Fasman. Boca Raton, Florida: CRC Press.

SVEnSSON, B., LARSEN, K. \& GuNNARSSON, A. (1986). Characterization of a glucoamylase G2 from Aspergillus niger. European Journal of Biochemistry 154, 497-502.

Takahashi, T., INOKushi, N. \& IRIE, M. (1978). Purification and some properties of three forms of glucoamylase from a Rhizopus species. Journal of Biochemistry 84, 1183-1194.

TAKahashi, T., INOKUSHI, N. \& IRIE, M. (1981). Purification and characterization of a glucoamylase from Aspergillus saitoi. Journal of Biochemistry 89, 125-134.

Tanaka, Y., Ashikari, T., Nakamura, N., Kiuchi, N., Shibano, Y., AMaCHI, T. \& Yoshizumi, H. (1986). Comparison of amino acid sequences of three glucoamylases and their structure-function relationships. Agricultural and Biological Chemistry 50, 965-969.

TsuboI, A., Yamasaki, Y. \& Suzuki, Y. (1974). Two forms of glucoamylase from Mucor rouxianus. 1. Purification and crystallization. Agricultural and Biological Chemistry 38, 543-550.

Yamasakı, Y., SuzukI, Y. \& OzaWa, J. (1977). Purification and properties of two forms of glucoamylase from Penicillium oxalicum. Agricultural and Biological Chemistry 41, 755-762. 